\title{
The Strength of a Loosely Defined Movement: Eugenics and Medicine in Imperial Russia
}

\author{
NIKOLAI KREMENTSOV* \\ Institute for the History and Philosophy of Science and Technology, University of Toronto, \\ 91 Charles Street West, Toronto, ON M5S 1K7, Canada
}

\begin{abstract}
This essay examines the 'infiltration' of eugenics into Russian medical discourse during the formation of the eugenics movement in western Europe and North America in 1900-17. It describes the efforts of two Russian physicians, the bacteriologist and hygienist Nikolai Gamaleia (1859-1949) and the psychiatrist Tikhon Iudin (1879-1949), to introduce eugenics to the Russian medical community, analysing in detail what attracted these representatives of two different medical specialties to eugenic ideas, ideals, and policies advocated by their western colleagues. On the basis of a close examination of the similarities and differences in Gamaleia's and Iudin's attitudes to eugenics, the essay argues that lack of cohesiveness gave the early eugenics movement a unique strength. The loose mix of widely varying ideas, ideals, methods, policies, activities and proposals covered by the umbrella of eugenics offered to a variety of educated professionals in Russia and elsewhere the possibility of choosing, adopting and adapting particular elements to their own national, professional, institutional and disciplinary contexts, interests and agendas.
\end{abstract}

Keywords: Eugenics movement, Nikolai Gamaleia, Tikhon Iudin, Russian medicine, Heredity, Public health

In the seminal 1990 volume, The Wellborn Science: Eugenics in Germany, France, Brazil, and Russia, its editor, Mark B. Adams, has called forcefully for a comparative approach to the history of eugenics, especially from the institutional and professional viewpoints, as a way of understanding both the national peculiarities and the transnational similarities in this ubiquitous twentieth-century phenomenon. ${ }^{1}$ I suspect that Adams's personal interest in the history of eugenics in one particular locale - Russia - has provided

* Email address for correspondence: n.krementsov@utoronto.ca

Funding for research leading to this article came from the Social Sciences and Humanities Research Council of Canada. A version of this article has been presented at a session on eugenics at the 2013 meeting of the American Association of the History of Medicine in Atlanta, GA, and I am grateful to the participants for their questions and suggestions. I would also like to thank the journal's anonymous reviewers for their thoughtful comments that helped improve the final text.

${ }^{1}$ Mark B. Adams (ed.), The Wellborn Science: Eugenics in Germany, France, Brazil, and Russia (New York: Oxford University Press, 1990). 
the main motivation behind this call, for that particular history offers a striking contrast to the historical trajectories of eugenics in other countries. Indeed the very first scholarly article on Russian eugenics published in 1977 by Loren R. Graham bore an explicitly comparative title and focused on (a few) similarities and (many) differences between Russian and German involvement with eugenics during the 1920s. ${ }^{2}$ Subsequent western scholarship has further emphasised the comparative value of the Russian case in the understanding of institutional structures, research agendas, ideological foundations and social policies advanced by eugenicists elsewhere. ${ }^{3}$ Indeed, although it shared certain features with its western counterparts, Russian eugenics' life-span, institutional and disciplinary composition, patronage pattern, social impact, public resonance and research foci differed substantially from those in other countries. ${ }^{4}$

Practically all historical studies of Russian eugenics, however, focus on its development after the Bolshevik revolution of 1917 and its links with the development of Russian genetics. ${ }^{5}$ Its actual history seems to justify this particular focus: first eugenic institutions indeed appeared in Russia only in the early 1920s and were indeed created by geneticists. Yet, during the two previous decades, while eugenics was quickly institutionalising in western Europe and North America and congealing into a transnational movement, eugenic ideas, practices and policies enticed wide debates among Russian physicians, sociologists, biologists, anthropologists, jurists and educators, even though these debates did not 'translate' into eugenic institutions, policies or calls to join the fledgling movement.

In this essay I examine this initial, 'pre-institutional' stage in the development of eugenics in Russia, focusing on reactions to eugenic ideas, methods, policies and ideologies by the medical community - the most active and vocal group among the Russian observers of eugenics at the time. My goals here are twofold. First, to sketch the process of eugenics's 'infiltration' into Russian discourse on human variability, diversity, evolution, reproduction, heredity and health and to understand why, despite the wide-ranging discussions, eugenics failed to find an institutional niche or legislative support in Imperial Russia. Second, to examine the nature of the emerging transnational eugenics movement itself through the lens of the Russian medical community's comments and criticisms.

Although the first Russian translation of Francis Galton's Hereditary Genius appeared in 1874 , the subsequent quarter of a century saw little interest in the eugenic ideas of 'betterment of humankind'. Yet, circa 1900, just as eugenics began its institutionalisation

${ }^{2}$ Loren R. Graham, 'Science and Values: The Eugenics Movement in Germany and Russia in the 1920s', American Historical Review, 82, 5 (1977), 1133-64.

${ }^{3}$ See Michael Flitner, 'Genetic Geographies: A Historical Comparison of Agrarian Modernization and Eugenic Thought in Germany, the Soviet Union, and the United States', Geoforum, 34 (2003), 175-85; A. Spektorowski, 'The Eugenic Temptation in Socialism: Sweden, Germany, and the Soviet Union', Comparative Studies in Society and History, 46 (2004), 84-106; Mark B. Adams, Garland E. Allen and Sheila Weiss, 'Human Heredity and Politics: A Comparative Institutional Study of the Eugenics Record Office at Cold Spring Harbor (United States), the Kaiser Wilhelm Institute for Anthropology, Human Heredity, and Eugenics (Germany), and the Maxim Gorky Medical Genetics Institute (USSR)', Osiris, 20 (2005), 232-62; Nikolai Krementsov, 'Eugenics, rassenhygiene, and human genetics in the late 1930s', in Susan G. Solomon (ed.), Doing Medicine Together: Germany and Russia Between the Wars (Toronto: University of Toronto Press, 2006), 369-404.

${ }^{4}$ For a general overview of the history of Russian eugenics during the three distinct periods in its development - Imperial (1900-17), Bolshevik (1917-29), and Stalinist (1930-9) - see Nikolai Krementsov, 'From "Beastly Philosophy” to Medical Genetics: Eugenics in Russia and the Soviet Union', Annals of Science, 68, 1 (2011), 61-92.

${ }^{5}$ For the only, but very circumscribed, attempt to examine the development of eugenics during the Imperial era, see B'ern M. Felder [Bjorn M. Felder], 'Rasovaia gigiena v Rossii: Evgenii Aleksandrovich Shepilevskii i zarozhdenie evgeniki v Rossiiskoi imperii', Istoriko-biologicheskie issledovaniia, 4, 2 (2012), 39-60. 
in western Europe and North America, eugenic, and specifically Galton's, ideas started to enter into Russian discussions. ${ }^{6}$ As far as I was able to ascertain, the very word 'eugenics' (evgenika) and a brief exposition of Galton's views on its meanings appeared in Russian for the first time in a 1902 anthropology textbook, written by Ludwik Krzywicky and entitled Psychical Races. ${ }^{7}$ Over the next few years various publishers issued Russian translations of works by some of the western proponents of eugenics, including Agnes Bluhm, Georg Buschan, Emile Duclaux, Alfons Fischer, August Forel, Kurt Goldstein, Max von Gruber, Karl Pearson, Elie Perrier, Théodule Ribot, Charles Richet, and Johannes Rutgers. ${ }^{8}$ Russia's budding professional communities of anthropologists, physicians, educators, sociologists, jurists and biologists took the eugenic ideas and agendas of their western colleagues under consideration, addressing various facets of eugenic research, policies and ideologies in professional and popular periodicals. At this time, physicians, not geneticists, constituted the largest and arguably the most vocal group that actively disseminated and discussed eugenic ideas, ideals and proposals.

The 'infiltration' of eugenics into Russian medical discourse occurred during the decade of great political and social upheaval, bracketed by the 1904-5 Russo-Japanese war and the First World War and punctuated by the recurrent epidemics of cholera, typhus, typhoid and the plague that ravaged the country. ${ }^{9}$ The economic hardships and the catastrophic defeat in the war with Japan (which resulted in the loss of the entire Russian fleet and of several important colonies in the Far East) fuelled workers' strikes and peasants' uprisings, as well as the indignation of the educated elites, throughout the empire. Frightened by the prospect of a full-scale revolution, on 17 October 1905, Tsar Nicholas II issued a Manifesto that promised to grant his subjects fundamental civil liberties, to institute the rule of law, and to create a Russian 'parliament' composed of elected representatives - the State Duma - as the highest legislative body, thus setting a path towards a constitutional monarchy. The October Manifesto (combined with decisive police and military actions against insurgents) proved effective in appeasing the population: by 1907 the revolutionary fervour that had threatened to overthrow the autocratic regime had subsided. Seizing the opportunity, the regime quickly negated on its libertarian promises: the first elected State Duma was dissolved, electoral laws changed, and the activists of revolutionary protests jailed or exiled. Yet, in contrast to this stifling of the country's social and political life, Russian rulers did introduce several important economic reforms aimed at promoting industrial development and agricultural growth.

For Russia's medical community, this decade proved particularly trying. The overwhelming majority of Russian physicians were civil servants, drawing an annual salary in the employ of various state agencies: the tsarist court, the army, the navy, and

\footnotetext{
${ }^{6}$ Compared to the ever-growing and variegated literature on the history of eugenics in other countries, the history of eugenics in Russia has attracted relatively little scholarly attention. For general overviews, see Adams, 'Eugenics in Russia', in Mark B. Adams (ed.), The Wellborn Science: Eugenics in Germany, France, Brazil, and Russia (New York: Oxford University Press, 1990), 153-229; and Krementsov, op. cit. (note 4).

${ }^{7}$ See Liudvik Krzhivitskii [Ludwik Krzywicky], Psikhicheskie rasy (St Petersburg: XX vek, 1902), 54-73; 21223.

${ }^{8}$ See, for example, Emil' Diuklo, Sotsial'naia gigiena (St Petersburg: D. Golov i A. Bol'shakov, 1904); Karl Pirson, Nauka i obiazannosti grazhdanina (Moscow: I.N. Kushnerev i K, 1905); Maks Gruber, Gigiena polovoi zhizni (Moscow: Pechatnoe delo, 1908); Iogannes Rutgers, Uluchshenie chelovecheskoi porody (Moscow: Suvorin, 1909); and Agnes Blium, Evgenika i etika (Moscow: Suvorin, 1909).

9 On the political, social, and economic situation in Russia during this period, see A. Ascher, The Russian Revolution of 1905: Russia in Disarray (Stanford, CA: Stanford University Press, 1988) and A. Ascher, The Russian Revolution of 1905: Authority Restored (Stanford, CA: Stanford University Press, 1992).
} 
regional or municipal local government bodies - the zemstvos. ${ }^{10}$ Less than a quarter of all Russian physicians were in private practice, mostly in urban areas of the empire's western provinces. Initiated by the Great Reforms of the 1860s Russian physicians' continuing efforts to gain greater professional autonomy and social authority were dashed by the defeat of the 1905-6 revolution in which many physicians had taken active part: in its aftermath more than one thousand physicians were fired, arrested and exiled. ${ }^{11}$ The hopes sparked by the October Manifesto that a new wave of reforms would finally grant Russian physicians the long-sought-after social and professional status did not materialise. The autocratic regime reasserted its control over the issues of medicine and public health, denying its medical professionals a voice and a place in the country's social and political developments. But the recurring epidemics of typhus, the plague, small-pox and, especially, cholera during the decade demonstrated that such control did not translate into the improvement of the epidemiological situation, the expansion of medical services and public health efforts or 'the health of the nation' more generally.

It was within these contexts that eugenics began to figure in Russian medical discourse. Representatives of two different specialties appeared most closely engaged with introducing eugenics to Russian audiences: public health doctors (hygienists) and psychiatrists. The editors of two influential professional journals - Nikolai Gamaleia, editor of Hygiene and Sanitation, and Tikhon Iudin, editor of Modern Psychiatry - played a pivotal role in this process. Yet despite extensive discussions that the nascent eugenics movement generated among Russian physicians at this time, they did not even consider joining it: there were no calls to create a eugenics society, to found eugenic research institutions, to pass eugenic legislation, or to attend international eugenics conferences. The Russian medical community's reactions to (and perceptions of) eugenics reveal much about their professional/disciplinary concerns and aspirations, as well as about the very nature of the early eugenics movement.

In the following two sections, I examine the path and attitude to eugenics by Gamaleia and Iudin, respectively. In the next one, I consider the differences and similarities in Gamaleia's and Iudin's approaches to eugenics ideas, practices and ideologies. And in the final section, I analyse the very nature of the early eugenics movement through the lens of the Russian observers' critiques and commentaries. The Russian reactions to eugenics strongly suggest that the early eugenics movement lacked cohesiveness and was in fact merely an aggregation of various 'national eugenics'. ${ }^{12}$ The loose mix of widely varying ideas, ideals, methods, policies, activities and proposals covered by the umbrella of eugenics offered to a variety of educated professionals in Russia (and elsewhere) the possibility of choosing, adopting and adapting particular elements to their own national, professional, institutional and disciplinary contexts, interests and agendas. This lack of cohesiveness, I argue, gave the movement a unique strength, facilitating the spread of eugenic 'gospel' around the world, and led in the first two decades of the twentieth century

\footnotetext{
${ }^{10}$ See John F. Hutchinson, 'Society, Corporation or Union? Russian Physicians and the Struggle for Professional Unity (1890-1913)', Jahrbucher für Geschichte Osteuropas, 30 (1982), 37-53; John F. Hutchinson, 'Politics and medical professionalization after 1905', in Harley D. Balzer (ed.), Russia's Missing Middle Class: The Professions in Russian History (Armonk, NY: M. E. Sharpe, 1996), 89-116.

11 For a detailed analysis of Russian physicians' professional aspirations, see Nancy M. Frieden, Russian Physicians in an Era of Reform and Revolution, 1856-1905 (Princeton, NJ: Princeton University Press, 1981); and John F. Hutchinson, Politics and Public Health in Revolutionary Russia, 1890-1918 (Baltimore, MD: Johns Hopkins University Press, 1990).

12 Clearly epitomised in the name of the first eugenic institution: 'the Galton laboratory for national eugenics'.
} 
to the establishment of 'national eugenics' in numerous countries of western Europe and the Americas. ${ }^{13}$ But not in Russia.

\section{A Tale of Two Cities: Bacteriology, Public Health and Eugenics}

In 1910, eugenics found an unlikely champion in Russia: Nikolai Gamaleia (18591949), one of the country's leading bacteriologists. That year Gamaleia founded a new professional journal, entitled Hygiene and Sanitation (Gigiena $i$ sanitariia), which became the first Russian periodical to address various eugenic issues systematically, to publish surveys, abstracts, and reviews of eugenic literature, and to attempt to apply eugenic ideas to Russian contexts. Gamaleia's path to eugenics was quite circuitous.

Gamaleia was born in Odessa to a wealthy family of landed gentry. ${ }^{14}$ The youngest of twelve children, he attended an elite private school and began his higher education at the nearby Novorossiiskii University under the eminent zoologist Elie Metchnikoff. Every summer he also spent a few months at the University of Strasbourg, attending lectures and practical courses on biochemistry (physiological chemistry, as it was called at the time) offered by Ernst Felix Hoppe-Seyler, one of the founders of the field and Europe's leading authority on it. Perhaps his experiences in Strasbourg (where he had also attended lectures by other members of the university's renowned medical faculty) prompted Gamaleia's decision to pursue a medical career. After graduation from Novorossiiskii University he enrolled in the country's premier medical school, the Military-Medical Academy (MMA) in St Petersburg. Since he already had a university degree, he was able to complete his studies at the academy in just three years. In 1883, at the age of twenty-four, Gamaleia received his diploma and returned to Odessa to start his medical practice. He created a small, well-equipped laboratory at his own house, joined the Odessa Medical Society, and obtained an unpaid internship at the Odessa City Hospital, specialising in nervous and psychiatric disorders. ${ }^{15}$ It seemed that the young doctor's path in the career of a respected family physician in his home town was set. But in just two years, the 'germ revolution' altered that path.

In July 1885, newspapers and magazines all over the world carried a sensational story about a nine-year old boy mauled by a rabid dog and saved from an inevitable and horrible death by a vaccine developed by two French scientists, Émile Roux and Louis Pasteur. Following this exciting announcement, dozens of people bitten by rabid animals from around the world flocked to Paris for the new treatment. So too did dozens of physicians who wanted to learn the techniques of producing and administering the anti-rabies vaccine. Russians (both patients and physicians) formed one of the largest groups that sought

\footnotetext{
${ }^{13}$ For a recent overview of 'world eugenics', see A. Bashford and Ph. Levine (eds), The Oxford Handbook on the History of Eugenics (New York: Oxford University Press, 2010).

14 Gamaleia's memoirs are the main source for reconstructing his life and career, see N.F. Gamaleia, 'Vospominaniia', in N.F. Gamaleia, Sobranie sochinenii, Vol. 5 (Moscow: Medgiz, 1953), 11-248. Written in the 1940 s, these memoirs are not always accurate in describing his activities during the imperial era. Thus he does not even mention his interest in and involvement with eugenics. Similarly, the most detailed and voluminous biography of Gamaleia omits this subject entirely. See Iu.I. Milenushkin, Nikolai Fedorovich Gamaleia: Ocherk zhizni i nauchnoi deiatel'nosti (Moscow: Izd. Akademii Nauk, 1954). A collection of Gamaleia's personal papers kept at the Archive of the Russian Academy of Sciences in Moscow (fond 691) also contains no material pertaining to this facet of his life and work. Gamaleia's role in the early development of Russian bacteriology is examined in Elizabeth A. Hachten, 'Science in the Service of Society: Bacteriology, Medicine, and Hygiene in Russia, 1855-1907' (unpublished PhD dissertation: University of Wisconsin, Madison, 1991).

15 See, for example, N. Gamaleia, 'Demonstratsiia bol'nogo s isteriei', Protokol zasedaniia obshchestva Odesskikh vrachei, 4 (1885), 85.
} 
admission to Pasteur's laboratory. As it happened, Gamaleia became one of the first to gain access to the famed French scientist and his laboratory.

On February 1, 1886, the Odessa Medical Society convened an unscheduled meeting to discuss an urgent matter: an anonymous donor had bequeathed one thousand roubles (a very considerable sum in those days) to fund the trip of an Odessa physician to Pasteur's laboratory to learn as much as possible about the new anti-rabies treatment in order to make it available in Russia. The donor specifically named one member of the Society, Dr Nikolai Gamaleia, as a strong candidate for the mission. Urged by the highly complimentary recommendation from Gamaleia's former mentor Metchnikoff, the Society's members agreed that he was indeed an ideal candidate: young, unmarried, fluent in French (as well as German, English, and Italian) and, thanks to his training in both biology and medicine, well prepared for undertaking laboratory research. The Society's chairman immediately cabled Pasteur, asking him for permission for Gamaleia to visit his laboratory. Pasteur granted permission, and ten days later, Gamaleia was in Paris. He spent four months there and, thanks to his persistence and charm, became one of the first foreign physicians to enter Pasteur's inner sanctum and to learn the full details of his methods. Upon his return home, Gamaleia published a detailed description of Pasteur's techniques, making it possible for Russian doctors to produce the French anti-rabies vaccine in their own laboratories. ${ }^{16}$

The unexpected sojourn in Paris dramatically affected Gamaleia's career. He abandoned his earlier interest in neurology and psychiatry: the rapidly growing field of bacteriology became his lifelong passion. In June 1886, with Metchnikoff's support, he founded Russia's first 'bacteriological station', modelled after Pasteur's laboratory, and became its first director. ${ }^{17}$ Within a few years he converted the station into a full-blown bacteriological institute. For the next two decades Gamaleia worked on a variety of bacteriological, immunological and sanitary issues in Odessa and neighbouring regions: studying pathogenic micro-organisms and devising new vaccines; conducting analyses of the city's drinking water and advocating the establishment of a new waste removal system; and publishing manuals and lecturing on bacteriology to professional and lay audiences. ${ }^{18}$ He was deeply engaged in the studies of infectious diseases in humans and animals, including rabies, anthrax, tuberculosis, the plague and cholera, with the latter becoming the subject of his doctoral dissertation defended at the MMA in 1892 - during the peak of one of the disease's deadliest outbreaks in Russian history. ${ }^{19}$

During all these years, Gamaleia never drew a salary from his various activities, supporting himself, his growing family, and to a considerable degree his research by

\footnotetext{
${ }^{16}$ N. Gamaleia, O metode Pastera predokhraneniia ukushennykh ot beshenstva (Odessa: Odesskii vestnik, 1886); and N. Gamaleia, 'Sposob predokhraneniia ot beshenstva Pastera', Kalendar' dlia vrachei vsekh vedomstv, 2 (1887), 11-25.

${ }^{17}$ On the establishment of the bacteriological 'station' in Odessa, see Hachten, op. cit. (note 14) and Elizabeth A. Hachten, 'In Service to Science and Society: Scientists and the Public in Late Nineteenth-Century Russia', Osiris, 17 (2002), 171-209. For a contemporary overview of the institutional development of Russian bacteriology, see N. Gamaleia, 'Bakteriologicheskie instituty v Rossii', Gigiena i sanitariia (hereafter - GiS), 5 (1910), 781-91; for a general history of the emergence of the so-called Pasteurian stations in Russia, see N.S. Stolygvo, 'K istorii otkrytiia pervykh pasterovskikh stantsii v Rossii', Iz istorii meditsiny (Riga), 2 (1959), 165-70.

18 See, for instance, N.F. Gamaleia, Osnovy obshchei bakteriologii (Odessa: Slavianskaia, 1899); and N.F. Gamaleia, Lektsii o patogennykh mikrobakh (Odessa: Merk, 1909).

${ }^{19}$ See N. Gamaleia, Etiologiia kholery s tochki zreniia eksperimental'noi patologii (St Petersburg: Stasiulevich, 1893). For a detailed historical analysis of cholera epidemics in Russia, see Charlotte E. Henze, Disease, Health Care and Government in Late Imperial Russia: Life and Death on the Volga, 1823-1914 (London: Routledge, 2011).
} 
the income from his family inheritance. But by 1909 the inheritance had run out and he was forced to start looking for a paying job. His reputation as a leading bacteriologist led Georgii Rein, the recently appointed head of the Medical Council of the Ministry of Internal Affairs ${ }^{20}$ - the country's highest medical advisory body - to offer Gamaleia the Council's newly created position of bacteriologist in St Petersburg. At the same time, the city's highest medical agency - its Sanitary Commission - offered him the post of chief inspector in charge of the city's numerous hostels and boarding houses. In 1909, at the age of fifty, Gamaleia left his beloved Odessa for St Petersburg.

The move marked a radical change in Gamaleia's life, work, and research. It transformed him from an independent researcher into a high-ranking public health officer. Since the Medical Council was a consultative body, it did not have any research facilities. It took Gamaleia more than two years to create a laboratory for his studies in St Petersburg. So, instead of laboratory research in bacteriology and immunology, he got deeply engaged in epidemiological studies and the organisation of preventive measures against a variety of endemic and epidemic diseases, which plagued the country as a whole and its capital's numerous slums more specifically.

Although Gamaleia was familiar with epidemiological research and had worked on various sanitary issues in Odessa, in St Petersburg he faced considerable new challenges. The two cities differed drastically in their economic, demographic, climatic, topographic and, hence, epidemiological profiles. ${ }^{21}$ During the second half of the nineteenth century both St Petersburg and Odessa experienced extraordinary rapid growth. From 1863 to 1897 the population of St Petersburg grew by 240 per cent, but during the same time Odessa's population exploded by a staggering 340 per cent, making it not only the fastest growing but also the third largest city in the empire. ${ }^{22}$ Located on the fringe of the country's most fertile lands on the warm shores of the Black Sea, Odessa was the trade capital of southern Russia, with its seaport serving as the main artery for the country's burgeoning agricultural exports. Accordingly, in Odessa, Gamaleia worked largely on human and animal diseases prevalent in the region or brought to the city via its seaport, most notably the plague, cholera and anthrax. ${ }^{23}$ In contrast, located on the cold, swampy shores of the Baltic Sea in the north-western part of the country, St Petersburg was the largest city of the empire, which served not only as its administrative capital, but also as its industrial hub, with huge factories, railroads and shipyards, each of which employed thousands of workers. Accordingly, while continuing his work on the epidemic diseases that ravaged the entire country such as cholera, smallpox and the plague, in St Petersburg Gamaleia shifted the main focus of his research to such endemic diseases of urban slums as typhus, typhoid and relapsing fever. $^{24}$

\footnotetext{
20 On Georgii Rein and his role in Russian medicine, see Hutchinson, op. cit. (note 11), 82-108.

${ }^{21}$ For an analysis of the interrelation of the processes of urbanisation and public health issues during this period, see William Gleason, 'Public Health, Politics, and Cities in Late Imperial Russia', Journal of Urban History, 16 (1990), 341-65.

22 See A.G. Rashin, Naselenie Rossii za 100 let (1811-1913) (Moscow: Gosstatizdat, 1956). The growth of Odessa slowed down in the next two decades, but it remained the country's fifth largest city on the eve of the First World War. For an overview of the city's history during the imperial era, see Patricia Herlihy, Odessa: A History, 1794-1914 (Cambridge, MA: Harvard University Press, 1987).

${ }^{23}$ See, for instance, N.F. Gamaleia and V.A. Belinskii, Chuma v Odesse, 2 vols (Odessa: [no publisher], 1903-04) and N.F. Gamaleia, Cholera i bor'ba s neiu (Odessa: [no publisher], 1905).

${ }^{24}$ N.F. Gamaleia, 'Ocherk epidemiologii vozvratnogo i sypnogo tifa i izlozhenie mer bor'by s nimi', GiS, 1 (1910), 126-37; 2: 195-205; 3: 326-41.
} 
The move also put Gamaleia in position of influence within the city's and the country's medical and civic bureaucracy. ${ }^{25}$ It involved him in heated debates, ranging from plans to create a 'ministry of health' to the revision of medical and sanitary legislation and the construction of St Petersburg's water supply system. It brought him into close contact with St Petersburg's medical community, the country's largest and most influential group of medical researchers and practitioners. In particular, his new job at the St Petersburg Sanitary Commission placed him in charge of a large and active cohort of young city physicians, who became his collaborators, colleagues and friends. ${ }^{26}$ Gamaleia immediately tapped the expertise of St Petersburg's medical community by organising an informal group, named 'The conference of slum physicians' (soveshchanie nochlezhnykh vrachei), which became a vehicle for implementing new ideas in tackling the city's epidemiological and sanitary problems. In just a few months on his new jobs, Gamaleia also founded a new professional periodical, Hygiene and Sanitation, which provided a forum for discussing the city's and the country's sanitary and epidemiological conditions. In early January 1910, the first issue of the biweekly journal - financed, edited and largely written by Gamaleia - came out.

In the programmatic editorial opening the journal Gamaleia confirmed the diagnosis that had been made by generations of Russian physicians: the empire was sick. ${ }^{27}$ As had many before him, Gamaleia supported this diagnosis by references to the country's fertility, mortality and morbidity rates, which far exceeded those of her western neighbours. He identified the main causes of this troubling situation:

There is no doubt that Russia's poor sanitary conditions are closely related to her weak economic, political and cultural development. Russia is characterised not only by high mortality and the wide spread of contagious diseases, but also by a huge rate of illiteracy, by constant famines and the predominance of primitive agricultural techniques, by minuscule industry, by the lack of roads, and so on. Compared to her neighbours, Russia is backward, ignorant and poor, and her sanitary conditions are in full accord with this general background. ${ }^{28}$

He asserted that making the country healthy - the 'healthification' of Russia (ozdorovlenie Rossii) $^{29}$ - was the main task of the medical community as a whole and of his journal in particular. (Indeed, his journal's subtitle stated directly that it was 'devoted to the investigation of issues of the healthification of Russia'.) Yet, Gamaleia did not subscribe to the remedy for these 'ills' of the empire - namely, political and economic reforms that had been forcefully advocated by a large majority of his fellow-physicians, especially among the membership of their most influential professional society, the Pirogov Society of Russian Physicians. ${ }^{30}$ Instead, he argued that 'sanitary progress depends, first of all, on sanitary actions'. To support this view, Gamaleia compared the country's two largest cities, Moscow and St Petersburg, 'sisters-in-ignorance, poverty, and unculturedness', yet strikingly different in their sanitary and epidemiological profiles:

Thanks to her water supply and sewage disposal systems, [in the last year] Moscow had only 200 cases of cholera and almost no typhoid, while St Petersburg [which at the time had neither a clean water supply nor sewage disposal systems - N.K.] had 16000 cases of cholera and occupies first place among the world's cities in the incidence of typhoid.

25 On Russia's medical bureaucracy during this period, see Hutchinson, op. cit. (note 11).

26 The city employed more than 150 physicians, about one half of them as school inspectors.

27 See [N. Gamaleia], '[Programma zhurnala]', GiS, 1 (1910), 1-5. Although the editorial was untitled and unsigned, it is clear that as the editor and owner of the journal Gamaleia penned it.

${ }^{28}$ Ibid., 5.

${ }^{29}$ For a discussion of the concept of ozdorovlenie (healthification) and its role in the ideology and activities of Russian physicians, see Hutchinson, op. cit. (note 11), xv-xx.

${ }^{30}$ For a detailed analysis of the Pirogov Society of Russian Physicians, see Frieden, op. cit. (note 11). 
This contrast, according to Gamaleia, demonstrated convincingly that, even in the absence of economic and political reforms, purely sanitary interventions could have a tremendous impact on the country's health. He outlined the journal's scope and direction, explaining that the 'hygiene' of its title covered the theoretical and research field of hygienic knowledge, while the 'sanitation' referred exclusively to the concrete applications of such knowledge. ${ }^{31}$ In the stifling atmosphere of the post-revolutionary years, it is perhaps hardly surprising that he concluded his editorial with a statement that 'a discussion of political and economic reforms' lay outside the purview of his journal: 'all our attention will be focused on those sanitary measures that are important for the healthification of Russia'. Among the various subjects that the journal was to cover to advance this agenda Gamaleia listed infectious diseases, clean water supply and sewage disposal, housing, school and occupational hygiene, demography and vital statistics, military and naval hygiene, and ... 'generative hygiene (eugenics)' ${ }^{32}$

Following this programmatic statement, the same issue carried the first of a series of detailed articles on eugenics. ${ }^{33}$ It also introduced a special bibliographic section 'on eugenics' that regularly published reviews and summaries of recent western books and articles appearing in such European periodicals as the British Eugenics Review, the German Archiv für Rassen- und Gesellschaftsbiologie and Zeitschrift für Sexualwissenschaft und Sexual-Politik, and the French La Presse Médicale and L'Hygiène Populaire. ${ }^{34}$ Among the various items on the subject, Hygiene and Sanitation carried a detailed essay of the history of eugenics, a lengthy report on the proceedings of the First International Eugenics Congress held in London in 1912, and a survey of the current views on heredity. ${ }^{35}$

It seems likely that Gamaleia's initial interest in eugenics was sparked by Kazimir Karaffa-Korbutt (1878-1935), a young, talented physician he first met after his move to St Petersburg. ${ }^{36}$ Trained as a surgeon (his doctoral dissertation defended in 1908 at the MMA dealt with renal diseases), Karaffa-Korbutt found his true vocation in public health research. In parallel with his job as a surgeon at a major hospital, he began working for the St Petersburg Sanitary Commission as one of its inspectors. Early in his professional career, Karaffa-Korbutt also developed a serious interest in the application of mathematics to medicine. ${ }^{37}$ It was because of this interest that he had become acquainted with the biometrical work of Francis Galton, Karl Pearson and their co-workers at the Galton Laboratory for National Eugenics. With its foundation in statistical research and its focus on 'the study of agencies under social control that may improve or impair the

${ }^{31}$ [N. Gamaleia], op. cit. (note 27) 5.

32 The term 'generative hygiene' (generativnaia gigiena) was a Russian translation of the German term 'Fortpflanzungshygiene'.

${ }^{33}$ See K.V. Karaffa-Korbutt, 'Ocherki po evgenike', GiS, 1 (1910), 41-8; 2: 138-45; 3: 276-81.

${ }^{34}$ See, for instance, Kazimir Karaffa-Korbut, 'I. Rutgers, Uluchshenie chelovecheskoi porody; Agnessa Blium, Etika i evgenika, SPb. 1909', GiS, 1 (1910), 75-6; N. G[amaleia], 'Bertillion', ibid., 4 (1910), 292-3; N. Avgustovskii, 'N. Norre, O zachatii v sostoianii op'ianeniia', ibid., 9 (1910), 670-1.

35 See 'Istoriia evgeniki: I.A. Fields, The progress of eugenics', GiS, 17-20 (1913), 286-90; [N. Gamaleia], 'Pervyi mezhdunarodnyi evgenicheskii kongress v Londone, 24-30 iiulia 1912', ibid., 15-16 (1912), 175-82; and K. Kuchuk, 'Kratkii ocherk sovremennykh vzgliadov na nasledstvennost', ibid., 21-22 (1912), 437-41.

${ }^{36}$ For a brief biography of Karaffa-Korbutt, see Iu.I. Rafes, 'Karaffa-Korbut - vydaiushchiisia gigienist Rossii i Pol'shi', GiS, 3 (1960), 50-3.

37 See K.V. Karaffa-Korbutt, Primenenie matematicheskikh metodov issledovaniia $v$ izuchenii meditsiny (St Petersburg: Ettinger, 1908). 
racial qualities of future generations, either physically or mentally, ${ }^{38}$ Galtonian eugenics obviously appealed to the young, mathematically minded physician who investigated the sanitary and epidemiological conditions of urban slums and markets. When Gamaleia organised 'The conference of slum physicians', Karaffa-Korbutt became one of its most energetic and active participants. ${ }^{39} \mathrm{He}$ also became Gamaleia's right-hand man in establishing Hygiene and Sanitation and defining the journal's scope and direction. ${ }^{40}$ It was Karaffa-Korbutt who in 1910 wrote a series of detailed articles for Gamaleia's journal, surveying the goals, methods and ideas of British eugenics and its German counterpart, 'racial hygiene'. ${ }^{41}$

But eugenics inspired Gamaleia too. He personally wrote several editorials discussing various facets of eugenic research and policies and reviewed several eugenic publications. ${ }^{42}$ Furthermore, in late November 1912 Gamaleia published a long article on 'the conditions favourable for the betterment of humans' natural qualities'. ${ }^{43}$ The First International Eugenics Congress (that had taken place in London in July of that year and whose contents Gamaleia had detailed on the pages of Hygiene and Sanitation) appeared to be the major stimulus for Gamaleia to take up his pen. His article presented a concise analysis of the basic eugenics ideas of 'racial degeneration' and 'regeneration', their scientific underpinnings in Charles Darwin's theory of natural selection and in the concepts of heredity advanced by Francis Galton, August Weisman and Gregor Mendel, and the proposed eugenic actions (both 'negative' and 'positive') to counter degeneration and to promote regeneration, all of which had been discussed extensively at the Congress.

Gamaleia questioned the validity of the main eugenic postulate of 'racial degeneration', seeing eugenics simply as an extension of 'social hygiene' to the issues of human reproduction: 'generative hygiene'. For Gamaleia, the rise of eugenics in Britain represented the culmination of a long process of social reforms, which had started in the mid-nineteenth century with wide sanitary and public health reforms, moved on to reform the legislation pertaining to the conditions of children and women labour in the factories, and then proceeded to introduce state-mandated education for all children. Now, according to Gamaleia, eugenicists were advocating for expanding these 'hygienic' reforms to the pre-school, pre-birth and even pre-conception stages in human life through an extensive 'care of the future mother'.

Gamaleia concluded that 'Russia, which is as yet in her first period of these social reforms [eg. sanitary and public health reforms - N.K.], is incapable of generating a strong eugenic movement, but she needs, nevertheless, to understand the problems that trouble her

\footnotetext{
${ }^{38}$ Francis Galton, 'Probability, the foundation of eugenics', in Francis Galton, Essays in Eugenics (London: The Eugenics Education Society, 1909), 81.

${ }^{39}$ See K.V. Karaffa-Korbutt, 'Nochlezhnye doma Sankt Peterburga', Obshchestvennyi vrach, 1 (1911), 81-9; the same article also appeared in GiS, 1 (1912), 7-25; 2: 69-85; Karaffa-Korbutt, 'Nochlezhnye doma v bol'shikh russkikh gorodakh', Gorodskoe delo, 10 (1912), 627-42; 11-12: 691-712; 13-14: 803-23.

40 See Z.G. Frenkel', Zapiski $i$ vospominaniia o proidennom zhiznennom puti (St Petersburg: Nestor-Istoriia, 2009), 228-29.

${ }^{41}$ See K.V. Karaffa-Korbutt, op. cit. (note 33), 41-8; 2: 138-45; 3: 276-81. Judging from the content of these three articles, Karaffa-Korbutt had originally planned a much longer series, with separate articles on biometrics, Galton, and German Rassenhygiene. But, although the last published article promised 'to be continued', no further articles appeared. I was unable to discover any reasons for this abrupt end of the series.

42 See, for instance, N. G[amaleia], 'Bertillion', GiS, 4 (1910), 292-3; and N. Gamaleia, '1 iiulia 1910 goda', ibid., 13 (1910), 1-5.

${ }^{43}$ N.F. Gamaleia, 'Ob usloviiakh, blagopriiatstvuiushchikh uluchsheniiu prirodnykh svoistv liudei', GiS, 19-20 (1912), 340-61.
} 
cultured neighbours. ${ }^{44}$ Through his journal he continued to further exactly that goal: to inform and educate Russian hygienists about eugenic debates and actions undertaken by their western colleagues.

But Gamaleia did not limit this activity to his journal. He included a special section on eugenics into the programme of 'practical courses for sanitary physicians' he offered at his laboratory during $1912 .{ }^{45}$ In early November 1912, while teaching bacteriology and hygiene in Iur'ev (now Tartu, Estonia), he delivered a series of public lectures on eugenics, which were reported in the city's major Estonian-language daily. ${ }^{46}$ On November 20, 1913 , Gamaleia also delivered a long talk on 'degeneration and regeneration of humans from a eugenics viewpoint' to a meeting of the St Petersburg Sanitary Society. ${ }^{47}$ At the end of 1913, Gamaleia stopped the publication of Hygiene and Sanitation. ${ }^{48}$ But despite his short-lived involvement with eugenics, Gamaleia and his journal proved highly influential in awakening Russian hygienists' interest in the subject. ${ }^{49}$

\section{A Tale of Two Other Cities: Psychiatry, Heredity and Eugenics}

Just as Gamaleia left the field, eugenics found another champion in Russia: Tikhon Iudin (1879-1949), a young but well-respected Moscow psychiatrist. In early 1914, Iudin became a co-editor of Modern Psychiatry (Sovremennaia psikhiatriia), the discipline's leading periodical. On the pages of this journal Iudin continued Gamaleia's mission of educating Russian physicians about eugenics. But Iudin's path to eugenics was much more direct, for his professional interests centred on the role of heredity in mental illness.

Information on Iudin's early life and career is rather sketchy. ${ }^{50}$ In 1903 he graduated with distinction from the renowned medical school of Moscow University. The faculty chose him for 'preparation for the title of professor' (what today we call graduate studies). He was appointed a junior intern at the university's psychiatric clinic headed by the eminent psychiatrist Vladimir Serbskii (1852-1917), where he began collecting material for a doctoral dissertation. At the clinic Iudin joined a group of young ambitious

44 Ibid., 361 .

45 See an advertisement for the courses in the 1912 yearbook of St Petersburg physicians, Ves' vrachebnyi Peterburg (St Petersburg, 1912), 105.

46 See Professor [N.F.] Gamalei [Gamaleia], 'Tõuterwenduse-õpetuse, eugeenika põhjus, mõtteist ja ulesannetest', Postimees (Tartu), 1912, 5-9 November; available at http://dea.nlib.ee/fullview.php?frameset=3\& showset=1\&wholepage=keskmine \&pid=s474228\&nid=7093; accessed April 27, 2014. I am grateful to Dr Julia Lajus for finding this link. Russian-language dailies were not published during this period due to a typesetters' strike and thus a Russian language account of Gamaleia's lectures never appeared.

${ }^{47}$ See N.F. Gamaleia, 'O vyrozhdenii i vozrozhdenii liudei po dannym eigeniki', Vrachebnaia gazeta, 7 (1913), 271.

${ }^{48}$ From 1913 onwards Gamaleia put most of his time and energies into the St Petersburg Smallpox Vaccination Institute he had founded in late 1912. See his voluminous manual on smallpox vaccination, N. Gamaleia, Ospoprivivanie (St Petersburg: Linnik, 1913); and Gamaleia, Ospa i bor'ba s nеiи v Petrograde (Petrograd: Kirkhner, 1915).

${ }^{49}$ For instance, contrary to the opinion of Bjorn M. Felder, it was Gamaleia who incited Evgenii A. Shepilevskii, professor of hygiene and bacteriology at Iur'ev University (where Gamaleia was teaching in 1911-1913), to take up the discussion of, and research into, racial hygiene. See Felder, op. cit. (note 5).

${ }^{50}$ Nowadays, Iudin is mostly remembered as the author of a voluminous history of Russian psychiatry: T. Iudin, Ocherki istorii otechestvennoi psikhiatrii (Moscow: Medgiz, 1951). Alas, aside from several commemorative articles and short notes in various encyclopaedia hailing him as a founder of Russian 'clinical genetics', there are no historical accounts of the life and work of this interesting man. See A.G. Galach'ian, 'T.I. Iudin kak osnovopolozhnik russkoi i sovetskoi klinicheskoi genetiki (k piatnadtsatiletiiu so dnia smerti)', Zhurnal nevrologii i psikhiatrii im. S.S. Korsakova, 65, 12 (1965), 1883-90; M.E. Vartanian, 'Tikhon Ivanovich Iudin (k 100-letiiu so dnia rozhdeniia)', Zhurnal nevrologii i psikhiatrii, 79, 12 (1979), 1748-53. I was also unable to locate Iudin's personal papers in the archives. 
doctors, including Sergei Sukhanov (1867-1915) and Petr Gannushkin (1875-1933), ${ }^{51}$ who had sought to reform their discipline, both in its administrative structures and in its scientific foundations, campaigning for the adoption of the new nosological and diagnostic approaches developed by their prominent German colleague Emil Kraepelin. ${ }^{52}$ In the heady atmosphere of the first Russian revolution, the issue of collegiality in the administration of psychiatric institutions became particularly contentious, with members of the group lobbying for an increased role for physicians and especially for junior personnel. In 1907, in protest against its director's authoritarian management practices, the group resigned from the clinic en masse. ${ }^{53}$

In search of new jobs they dispersed through the country's psychiatric institutions: Sukhanov moved to a psychiatric clinic in St Petersburg, Gannushkin to the Moscow City Psychiatric Hospital (Kanatchikova dacha), and Iudin to Kharkov psychiatric asylum run by the provincial zemstvo (Saburova dacha) ${ }^{54}$ But they did not abandon their plans to reform their discipline. Later that same year, 1907, led by Gannushkin, they established a new journal, provocatively entitled Modern Psychiatry, which provided a forum for the discussion and dissemination of modern ideas in psychiatric theory, research and practice in Russia. ${ }^{55}$ One such idea was the role of heredity in mental illness - the subject of Iudin's doctoral dissertation.

The idea that heredity plays a role in pathology, more generally, and in the development of mental illness, in particular, had had a very long history. ${ }^{56}$ In psychiatry, empirical observations that certain psychiatric disorders 'run in the family' had cast heredity into the ultimate 'explanation' for those clinical cases in which no obvious cause (either external or internal) for the onset of such disorders could be readily determined. Circa 1900, two independent, but similarly revolutionary, developments - one in psychiatry and another in biology - converged to give this old idea new meanings and new importance. The novel concepts of inheritance advanced by Darwin, Galton, Weismann, Mendel and their numerous followers had dramatically changed the very notion of heredity. Around the same time, Emil Kraepelin's new nosological and diagnostic approaches displaced the old 'symptomatic' psychiatry and profoundly changed the understanding of mental illness,

51 The group also included Aleksandr Bernshtein, Mikhail Lakhtin, and Ivan Vvedenskii.

52 Early in his career, from 1886 to 1891 , Kraepelin served as a professor of psychiatry at Iur'ev University, which certainly helped popularise his views among Russian psychiatrists. See Wolfgang Burgmair, Eric J. Engstron, and Matthias M. Weber (eds), Emil Kraepelin 7 vols (Munich: Belleville, 2000-8), especially Vol. 4: Kraepelin in Dorpat, 1886-91.

53 The activity of this group is partially examined in Irina Sirotkina, Diagnosing Literary Genius (Baltimore, MD: Johns Hopkins University Press, 2001).

54 On Iudin's work in Kharkov, see V.N. Kuznetsov, A.P. Petriuk and P.T. Petriuk, 'Professor Tikhon Ivanovich Iudin—krupneishii otechestvennyi psikhiatr i byvshii saburianin (k 130-letiiu so dnia rozhdeniia)', Psikhichne zdorov'ia, 2 (2009), 154-9.

55 At that time, there were three specialised periodicals on psychiatry and neurology in Russia: Neurological Herald (Nevrologicheskii vestnik), founded in 1893 and edited by Vladimir Bekhterev in Kazan; Review of Psychiatry, Neurology and Medical Psychology (Obozrenie psikhiatrii, nevrologii i meditsinskoi psikhologii), founded in 1896 and edited by Bekhterev in St Petersburg; and the Journal of Neuropathology and Psychiatry (Zhurnal nevropatologii i psikhiatrii), founded in 1901 and edited by Serbskii in Moscow.

${ }^{56}$ For the early history of the concept of heredity, see C. Lopez-Beltran, 'Forging Heredity: From Metaphor to Cause, A Reification Story', Studies in History and Philosophy of Science, 25 (1994), 211-35; and Staffan Müller-Wille and Hans-Jörg Rheinberger (eds), Heredity Produced: At the Crossroads of Biology, Politics, and Culture, 1500-1870 (Cambridge, MA, MIT Press, 2007); for a discussion of interrelations between the early notions of heredity and 'betterment of mankind', see John C. Waller, 'Ideas of Heredity, Reproduction and Eugenics in Britain, 1800-75', Studies in History and Philosophy of Biological and Biomedical Sciences, 32, 3 (2001), 457-89. 
especially, psychoses. These two 'revolutions' stimulated some psychiatrists' attempts to transform the vague umbrella term 'heredity' into a plausible aetiological category that could be not merely invoked but also investigated. ${ }^{57}$

Iudin's early publications illustrate this transformation vividly. After joining the staff of the Moscow University Psychiatric Clinic in 1903, he began collecting material related to the questions of hereditary origins of psychiatric diseases. It seems likely that Iudin took up this particular subject for his dissertation on the suggestion of one of his older colleagues, Sergei Sukhanov. Although Sukhanov's main research interest and the subject of his own doctoral dissertation was epilepsy, in 1900, he had also published a long article 'on psychoses in twins'. ${ }^{58}$ The article surveyed twenty-nine cases of psychiatric disorders in twins he had identified in the available literature and presented a detailed description of one case that Sukhanov had personally observed in the clinic and that had obviously sparked his interest in the subject. He concluded that 'some cases' clearly illustrated 'the inherited pathological organization of the nervous system' and 'the primary role and importance of heredity' in the development of mental illness. In his opinion, since 'psychiatric phenomena depend on the physical organization of our organism', his studies of twins (who obviously shared the same 'physical organization') lent credence to the idea that 'a similar organization of the nervous system results in similar pathological disorders'.

Iudin expanded upon Sukhanov's observations. His first article bore almost the same title as Sukhanov's and appeared in January 1907 in the Journal of Neuropathology and Psychiatry edited by Serbskii. ${ }^{59}$ Iudin added fourteen more cases of 'psychoses in twins' which had been described in the literature since Sukhanov had published his work, as well as one case he himself had observed in the clinic. He analysed all forty-five cases in detail, using Kraepelin's diagnostic and nosological categories and noting similarities and differences in the time of the onset, forms and progression of psychiatric disorders in twins. He attempted to establish a specific pattern that would allow him to distinguish the role of heredity and the role of such 'external' factors as similar prenatal and postnatal conditions, infections, nutrition and intoxications in 'twin psychoses'. He could not come to any definite conclusion, lamenting the paucity of data and the lack of uniformity in the available case histories. As had Sukhanov, in this article Iudin did not discuss heredity as such, limiting his analysis exclusively to clinical observations and results of patients' anamnesis.

Iudin's next article, which appeared in instalments in three consecutive issues of Modern Psychiatry at the end of 1907, was different. ${ }^{60}$ Entitled 'On the similarity of psychoses in brothers and sisters' and based on the materials Iudin had dug out from the archive of the Moscow University Psychiatric Clinic, it analysed the case histories of twelve pairs of siblings who had been treated at the clinic. In eight cases, Iudin found close resemblance in the form, intensity and longevity of psychoses among siblings, which, in his opinion, confirmed an important role played by heredity in mental illness. He noted that the majority of psychiatrists who had previously investigated the similarity of psychoses within families had resorted to a Lamarckian view of heredity. He asserted that now it

\footnotetext{
${ }^{57}$ Kraepelin himself became closely involved with the nascent German Rassenhygiene movement. He, however, remained a proponent of the 'old' Lamarckian notion of heredity, see Eric J. Engstrom, “'On the Question of Degeneration” by Emil Kraepelin (1908)', History of Psychiatry, 18, 3 (2007), 389-404.

58 S. Sukhanov, 'O psikhozakh u bliznetsov', Klinicheskii zhurnal, 4 (1900), 341-52.

59 T. Iudin, 'Psikhozy u bliznetsov', Zhurnal nevropatologii i psikhiatrii, 7, 1 (1907), 68-83.

60 T. Iudin, 'O skhodstve psikhozov u brat'ev i sester', Sovremennaia psikhiatriia (hereafter-SP), 10 (1907), 337-42; 11: 401-9; 12: 451-9.
} 
was necessary to re-evaluate this phenomenon in light of Weismann's research that had disproved the notion of the inheritance of acquired characteristics. Iudin admitted that 'these questions cannot be answered by [investigating] the similarity of psychoses in brothers and sisters, e.g. within one generation, but the verification of [the existence of] such similarity shows a certain way to answering them'.

Iudin's move to Kharkov deprived him of the access to the rich archive of the Moscow University Psychiatric Clinic that had supplied the data for his articles. But the issues of heredity remained at the forefront of his attention and he continued to collect relevant clinical cases. ${ }^{61}$ Four years later, at the First Congress of the Russian Union of Psychiatrists and Neurologists held in Moscow in September 1911, Iudin presented a long report 'On the nature of hereditary relationships in mental illness.' ${ }^{\prime 2} \mathrm{He}$ began his report with a succinct overview of dramatic changes in the understanding and investigating of heredity that had occurred during the last decade, including the re-discovery of Mendel's laws, the introduction of the concepts of 'pure line', 'genotype', and 'phenotype', and the numerous new discoveries in experimental embryology and cytology. ${ }^{63} \mathrm{He}$ stated that these changes necessitated similar developments in the understanding and investigating of the role of heredity in mental illness. He asserted that "the goal of investigating heredity in pathology must be the identification of "genotypes", "pure lines" (in [Wilhelm] Johannsen's terminology) with the same constant heredity, though varying to a certain degree'. According to Iudin, this goal required the adoption of new methods of investigation, namely, 'the individual study of separate families: a study of perhaps very few, but clinically thoroughly followed-up cases', by constructing genealogical tables of direct hereditary lineages in several generations of each particular family. Iudin provided examples of such new investigations conducted by British, German, Swiss and US researchers. He summarised the results of these studies, noting that in certain cases the inheritance of psychiatric disorders appeared to follow Mendel's laws and that in many cases such disorders were apparently inherited as recessive traits.

Iudin concluded his report with an analysis of twenty-one cases of the manifestation of mental illness in one family, which he had collected in his own practice at the Kharkov clinic: in eight cases the observations were limited to one generation, and in thirteen to two generations of the same family. He lamented that 'under the conditions prevalent in zemstvo hospitals, the collection of such material is extraordinary difficult' and thus his cases could be used 'only as an illustration' but not as a factual confirmation of the concepts advanced in the western literature.

After the congress, in late 1911, Iudin left Kharkov for Moscow to join the staff of the Moscow City Psychiatric Hospital. It seems likely that his old friend Gannushkin who worked at the hospital as a consultant physician orchestrated this move. Iudin also became a permanent member of the editorial staff of Modern Psychiatry run by Gannushkin and

${ }^{61}$ See T. Iudin, 'O forme dushevnykh zabolevanii, vstrechaiushchikhsia v sem'e progressivnykh paralitikov', $S P$, $1-2(1911), 126-43$

62 Iudin published a revised and expanded text of his report two years later, see T.I. Iudin, 'O kharaktere nasledstvennykh vzaimootnoshenii pri dushevnykh bolezniakh', $S P,(1913)$ (August), 568-79; the same article also appeared in the congress's proceedings that came out one more year later, see Trudy pervogo s'ezda russkogo soiuza psikhiatrov i nevropatologov (Moscow: Tipografiia Shtaba Moskovskogo voennogo okruga, 1914), 85463.

63 Iudin's main source of information on these issues was a Russian translation of Oscar Hertwig's book, Der Kampf um Kernfragen der Entwicklungs- und Vererbungslehre (Jena: Fischer, 1909), which appeared in late 1910, see Oskar Gertvig, Razvitie i nasledstvennost': Osnovnye i spornye voprosy biologii (St Petersburg: Obrazovanie, 1910). 
came to head the journal's bibliographic and 'chronicle' sections. His personal interests were clearly reflected in the materials that soon began to appear in the journal: Iudin actively solicited and himself published reviews and summaries of various studies on the role of heredity in mental illness. ${ }^{64}$ In early 1914, Iudin joined Gannushkin as a co-editor of the journal, and in April he published his first lengthy article 'on eugenics and the eugenic movement'. ${ }^{65}$

Iudin's article picked up the overview of eugenics exactly where Gamaleia had left it, surveying the development of the field after the First International Eugenics Congress. But his take on the subject differed considerably from that of Gamaleia. According to Iudin, eugenics was an 'applied science' and, as such, it 'depends on scientific data gathered by other theoretical disciplines, first of all, by genetics - the science of heredity'. In his opinion, 'genetics had directed and still directs the course of eugenics; the successes of the eugenics movement in the last years to a considerable degree are explained by and depend on the successes in the study of heredity'.

Iudin emphasised that the current views ascribed to heredity an exclusive role in defining the 'quality of progeny', with environmental influences, ranging from hygiene to education, capable of only modifying what was already present in the heredity of an individual, which s/he had received from parents. Citing Reginald Punnett, Professor of Genetics at the University of Cambridge and the editor of the Journal of Genetics, ${ }^{66}$ and Karl Pearson, head of the Galton Laboratory for National Eugenics and the editor of Biometrika, he stressed that the proponents of both the Mendelian and the biometric schools in the study of heredity supported this view, which thus provided the major scientific foundation for eugenic ideas and practices. Iudin pointed out that 'this scientific belief in the negligible influence of environment on heredity' prompted 'some eugenicists' to advance certain 'questionable ideas', such as the ideas of racial superiority and inferiority, and to advocate 'decisive policies', such as the sterilisation, segregation, and even euthanasia of individuals with 'inferior' heredity.

Iudin noted the strong negative reaction such ideas and policies provoked among various observers, including Russians. But, he stressed, it would be wrong to judge the entire eugenic movement by these 'fanatical' ideas and policies. He approvingly cited the opinion of William Bateson, the 'founding father' of genetics, that at the moment the scientific knowledge of heredity was far too sketchy even to think of its application to humans. Iudin also referred to the opinion of Carl Correns, a leading German geneticist who had played a prominent part in the rediscovery of Mendel's laws, that the majority of 'bad' hereditary traits (such as Iudin's own subject, mental disorders) were recessive and remained 'invisible' in the progeny, and thus any selection against these traits promoted by eugenics 'cannot lead to their elimination'. ${ }^{67}$ Iudin noted that some eugenicists focused on 'positive' as opposed to 'negative' eugenic measures, searching for ways to encourage the propagation of 'good' heredity in future generations. Through active propaganda campaigns, Iudin stated, they sought to instil basic eugenic ideas in the population to make these ideas part of 'unconscious' social mores, or even 'religious dogmas', that

\footnotetext{
${ }^{64}$ See, for instance, SP, 5 (1912), 392-401; and SP, 6 (1913), 819-23, 903, 958-65.

65 T.I. Iudin, 'Ob evgenike i evgenicheskom dvizhenii', SP, 4 (1914), 319-36.

66 Just a few months earlier, a Moscow publisher had issued a Russian translation of the 3rd revised and expanded edition of Punnett's classic textbook, Mendelism (London: Macmillan, 1911), which Iudin used in his survey: see R. Pennet, Mendelizm (Moscow: Bios, 1913).

${ }^{67}$ Iudin used a Russian translation of Correns's book, Die neuen Vererbungsgesetze (Berlin: Borntraeger, 1912), which had appeared just a few months earlier: K. Korrens, Novye zakony nasledstvennosti (Moscow: Bios, 1913).
} 
would guide individuals' decisions regarding marriage partners or the desirable number of children in the family.

Iudin observed that the 'eugenics movement has spread in a great wave through the cultured world'. He provided a detailed overview of eugenic institutions, societies, journals, activities and legislative initiatives in Britain, Denmark, France, Germany, Italy, Norway, Sweden and the United States, identifying leading figures in the national eugenic organisations of each country. He underlined a great variety of approaches to the ultimate goal of eugenics - the improvement of the human race - advocated by different individuals, as well as national particularities in the justifications of, and the attempts to attain, this goal, noting, for instance, that US eugenicists were much more enthusiastic about 'negative' eugenics than were their British or French colleagues. He described the continuing efforts to unite national eugenic organisations, which had begun at the First International Eugenics Congress in London and which, he was sure, would further invigorate the eugenics movement at the next international congress scheduled to meet in New York City in September 1915. He concluded his overview with a cautious endorsement:

Of course, at the present, the theoretical substantiation of, and investigations in, eugenics are at the very beginning, and the time when, on the basis of existing knowledge, we would have a right to intervene in social life on a large scale is still far in the future. But the efforts to advance the very idea of the necessity of greater care regarding the health of future generations, the education of humankind in the spirit of this idea, its propaganda, the creation of common sentiment conducive to eugenics, [and] active support for scientific research in this direction, perhaps, will indeed prove very beneficial for entire humankind. In any case, eugenic ideas deserve serious attention and study (336).

Undoubtedly, Iudin himself was planning to pay 'serious attention' to such studies in his own field, psychiatry. In June, he published in Modern Psychiatry a detailed review of the recently enacted British Mental Deficiency Act (April 1914), which some eugenicists hailed as a victory for their campaign to educate the public regarding the dangers of 'feeble-mindedness' to the nation's health. But the Great War that erupted in August put a stop to Iudin's plans: he was conscripted into the army and posted to the front. ${ }^{68}$

\section{Elective Attractions: The Strength of a Loosely Defined Movement}

What can we make of Gamaleia's and Iudin's involvement with eugenics? Why did these representatives of two completely different medical specialties find the subject worthy of the attention of their respective disciplines?

For Russian observers, the first point of attraction was that eugenics had emerged and developed among Russia's western 'cultured' neighbours: both Gamaleia and Iudin emphasised this point and consistently used the very term 'cultured' in their surveys. Many among the Russian educated public saw their country as backward, underdeveloped and 'uncultured' in comparison to western counterparts, an attitude that Gamaleia's 1910 editorial clearly reflects. The catastrophic failure of the 1904-5 Russo-Japanese war further heightened this perception. As Gamaleia observed in the same editorial, 'Before our very eyes, poor and ignorant Japan had left behind centuries of barbarism and moved to the centre of progress and culture', which, he implied, had certainly contributed to the Japanese decisive military triumph over the much larger, but 'backward', empire. ${ }^{69}$

${ }^{68}$ Iudin was able to return to his research only after the Bolshevik revolution of 1917.

69 [N. Gamaleia], op. cit. (note 27), 4. 
In the course of the nineteenth century Russian observers carefully monitored western developments in all spheres of life: science, industry, education, politics, agriculture, warfare, law, medicine and social policies. They published reviews, surveys and analyses of the latest western advances on the pages of such influential magazines as the Herald of Europe (Vestnik Evropy), Russian Wealth (Russkoe bogatstvo), and Russian Thought (Russkaia mysl'), which were considered obligatory reading by the Russian intelligentsia. They thoroughly examined specific exemplars, models, trajectories and templates of such western advances and hotly debated the necessity of emulating or rejecting them in their own practices.

Russian physicians in particular looked at their western colleagues as their teachers and models. A foreign trip (one- or two-years-long) was an essential part of 'preparation for the title of professor' in medicine (and natural sciences more generally). ${ }^{70}$ Practically all of Russian elite physicians and medical scientists spent time abroad, studying and conducting research under the tutelage of eminent specialists in their chosen fields at various clinics and universities in Germany, France and Austria, and, occasionally, in Britain, Italy and the United States. Although the majority of Russian physicians had reading knowledge of French and German, they regularly translated into Russian the newest monographs written by their western colleagues. They systematically abstracted and reviewed western publications in their own professional periodicals in each and every medical field. During the 1880 s and 1890 s, they even published a special journal, International Clinics (Mezhdunarodnaia klinika), devoted in its entirety to translations of current western literature. Furthermore, circa 1900, a significant number of Russian textbooks in various medical specialties were translations of, or compilations from, German and French ones. ${ }^{71}$

The 'western character' of early eugenics and the very fact (noted by both Gamaleia and Iudin) that the eugenics movement encompassed nearly all of the countries of the 'cultured world', including Britain, France, Germany, Italy, Scandinavia, and the United States, obviously warranted Russian observers' attention. Furthermore, the engagement (either actual or symbolic) of a number of eminent western physicians and scientists with early eugenics added substantially to the subject's allure in the eyes of their Russian colleagues. In this respect, eugenicists' claim of Charles Darwin's evolutionary theory as the scientific foundation of their doctrines weighed heavily in favour of eugenics in the eyes of Russian physicians and naturalists, who nearly unanimously considered themselves 'Darwinists'. ${ }^{72}$ Russian assessments always stressed the facts that the 'founding father' of eugenics Francis Galton was Darwin's cousin, while Darwin's son, Leonard, presided over the British Eugenics Education Society and the First International Eugenics Congress.

\footnotetext{
${ }^{70}$ For a detailed analysis of this phenomenon, see A.N. Dmitriev, 'Zagranichnaia podgotovka budushchikh rossiiskikh professorov nakanune Pervoi mirovoi voiny', in N.V. Gribovskii and S.F. Fominykh (eds), Professorsko-prepodavatel'skii korpus rossiiskikh universitetov, 1884-1917: Issledovaniia i dokumenty (Tomsk: Tomsk University Press, 2012), 65-76.

71 See, for instance, the systematic catalogues of books acquired from 1870 to 1898 by the MMA library: G.G. Skorichenko (ed.), Sistematicheskii knizhnyi katalog biblioteki Imperatorskoi Voenno-meditsinskoi akademii, 4 vols (St Petersburg: [no publisher], 1901-3); and a similar catalogue of the MMA student library, G.G. Skorichenko (ed.), Sistematicheskii katalog knig i zhurnal'nykh statei: Biblioteka studentov Voennomeditsinskoi akademii (St Petersburg: [no publisher], 1904).

72 On the reception of Darwinism in Russia, see Daniel P. Todes, Darwin without Malthus (New York: Oxford University Press, 1989) and Alexander Vucinich, Darwin in Russian Thought (Berkeley, CA: University of California Press, 1988).
} 
Both Gamaleia and Iudin perceived eugenics as a movement that blended together science, ideology and policy, noting considerable differences in the movement's manifestations in separate countries, most clearly expressed in the different names it assumed in various local settings. Both attempted to discern certain common features behind the diversity of 'national eugenics' and to give their readers a clear understanding of shared eugenic goals, actions, ideals, research methods, justifications and proposals, at the same time, assessing their applicability to Russian contexts.

As respected leaders of their medical specialties and influential members of the Russian medical community that saw the 'healthification' of their country and its population as their primary task, both Gamaleia and Iudin certainly found the ultimate goal of eugenics - the improvement of the human race 'physically or mentally' - quite appealing. As the newest trend in western discourse on human variability, diversity, evolution, reproduction, heredity and health, which might have important implications for a host of social policies with direct impact on the 'health of the nation', eugenics fell squarely in the category of western examples deserving serious consideration by Russian physicians. A particular focus on 'future generations' with its pronounced emphasis on the health of the child and the mother clearly discernible in many early eugenic debates, proposals, and activities (such as 'better baby contests', for example) also resonated strongly with Russian physicians' deep concerns over high infant and maternal mortality and morbidity rates in the empire.

Yet, both Gamaleia and Iudin were quite sceptical about 'racial degeneration' as the major justification for the necessity and urgency of eugenic actions, and particularly, about its applicability to Russia. To begin with, both read the very term 'race' as meaning humankind, humanity as a whole. Espoused by many western eugenicists the doctrine of racial hierarchies - of 'inborn' superiority or inferiority of certain races - had very limited following in Russia. ${ }^{73}$ Thus, Gamaleia simply chose to ignore the clear racist undercurrents in early eugenics, while Iudin insisted that the movement as a whole should not be judged by such occasional 'fanatical', as he termed them, interpretations. Other Russian commentators, however, were much more outspoken. In his reportage in Russian Wealth, Isaak Shklovskii, a well-known journalist who covered the proceedings of the 1912 London congress for the Russian press, put it bluntly, under the telling title 'Beastly Philosophy': 'all this, purportedly scientific, data, upon which the doctrine of higher and lower races are based, cannot withstand criticism, for a very simple reason that anthropology knows of no pure races'. ${ }^{74}$

For many proponents of eugenics in western Europe, a main sign of 'racial degeneration' was the decline of birth rates in general and among the 'better-off' classes in particular, which they had discovered in the vital statistics of their own countries. Thus, one of their major 'eugenic' goals was to increase low birth rates. But this particular sign of 'racial degeneration' appeared completely inapplicable to the Russian empire that had the highest fertility rate of all European countries. Even though in his overview, Gamaleia noted a slight decrease of the fertility rate in the recent decades, he pointed out that, for Russian physicians, the biggest problem was not to arrest the falling of the birth rates, but to

73 For a general history of physical anthropology and the concept of race in Imperial Russia, see Marina Mogil'ner, Homo Imperii: Istoriia fizicheskoi antropologii v Rossii (Moscow: NLO, 2008). See also Nathaniel Knight, 'Vocabularies of difference: Ethnicity and race in late Imperial and early Soviet Russia', Kritika: Explorations in Russian and Eurasian History, 13, 3 (2012), 667-83.

74 Dioneo [Isaak Shklovskii], 'Iz Anglii: Zverinaia filosofiia', Russkoe bogatstvo 10 (1912), 296-323, here - 302. 
decrease the appallingly high mortality and morbidity rates among infants, children, and their mothers.

Another major sign of 'hereditary degeneration' regularly invoked by western eugenicists was the proliferation of 'social ills' - criminality, feeble-mindedness, prostitution, alcoholism, venereal and tubercular diseases, suicide, pauperism and so on - which they believed were rooted in, and propagated by, 'bad' heredity, particularly among the 'lower classes'. The majority of Russian commentators on such 'social ills', however, ascribed the leading role in the rising numbers of criminals, paupers, alcoholics, prostitutes, mentally ill people, suicides, and other 'undesirables' in the empire not to biological causes (eg. individuals' heredity), but to social - and, first of all, political and economic causes. ${ }^{75}$ For example, in the autumn of 1910, Herald of Europe carried an article written by Vladimir Bekhterev, Russia's most eminent neurologist and psychiatrist, which fell nothing short of a fierce diatribe against capitalism and autocracy as the leading causes in the deterioration of mental health in the Russian population. Acknowledging that heredity played a role in various mental disorders, Bekhterev insisted that 'capitalism was the main evil of our times' and linked the growing 'alcoholisation' of the Russian population to the fiscal policies of the tsarist government that used sales of alcohol as the main source of revenue. ${ }^{76}$ It is quite telling that Gamaleia deemed it important to publish an expansive laudatory overview of Bekhterev's invective on the pages of his own journal. ${ }^{77}$ Gamaleia also published a similar lengthy condemnation of the Russian government's neglect of children's health as the leading cause of 'degeneration', written by Professor Nikolai Novombergskii, of Tomsk University, a well-known jurist, sociologist, and historian of medicine. ${ }^{78}$

Iudin, for his part, advanced a pointed critique of the very concept of 'hereditary degeneration', noting that its author, Bénédict Augustin Morel, had based his reasoning on the Lamarckian notion of the inheritance of acquired characteristics. ${ }^{79}$ According to Iudin, contemporary research in genetics thoroughly undermined this notion, thus making the entire concept of hereditary degeneration obsolete. To support his position, Iudin

\footnotetext{
75 There exists a vast literature examining Russian attitudes towards such 'social ills', for instance, Laura Engelstein, The Keys to Happiness: Sex and the Search for Modernity in fin-de-Siècle Russia (Ithaca, NY: Cornell University Press, 1994); Patricia Herlihy, The Alcoholic Empire: Vodka \& Politics in Late Imperial Russia (New York: Oxford University Press, 2002); Susan K. Morrissey, Suicide and the Body Politic in Imperial Russia (Cambridge: Cambridge University Press, 2012); and many others. None of these works, however, looks at the contemporary eugenic debates regarding these issues in any detail.

76 V. Bekhterev, 'Voprosy dushevnogo zdorov'ia v naselenii Rossii', Vestnik Evropy, 9 (1910), 294-306. See also a voluminous article written by a well-known 'public physician' Lev Granovskii for the journal of the Pirogov Society under the telling title, 'Public health protection and capitalism', L.B. Granovskii, 'Obshchestvennoe zdravookhranenie i kapitalizm', Zhurnal Obshchestva russkikh vrachei v pamiat’ N. I. Pirogova, 5 (1907), 371404; 6 (1907), 539-64.

77 See D. Zeilinger, 'Professor Bekhterev', GiS, 22-3 (1910), 606-8.

78 See Nikolai Novombergskii, 'Po puti k vyrozhdeniiu: Sotsial'no-gigienicheskie ocherki', GiS, 5-6 (1913), 201-34.

79 On the history of the concept of degeneration, see J. Edward Chamberlin and Sander L. Gilman (eds), Degeneration: The Dark Side of Progress (New York: Columbia University Press, 1985); and Daniel Pick, Faces of Degeneration: A European Disorder 1848-1918 (Cambridge: Cambridge University Press, 1989). For an attempt to investigate the influence and popularity of Morel's concept of degeneration in Russia, see Daniel Beer, Renovating Russia: The Human Sciences and the Fate of Liberal Modernity, 1880-1930 (Ithaca, NY: Cornell University Press, 2008). The latter work, however, completely fails to contextualise the Russian reception of Morel's concept and to discuss its relations to debates on eugenics. See critical reviews of the book by Daniel P. Todes (Isis, 100, 3 (2009), 664-5); Marina Mogilner (Kritika, 11, 3 (2010), 661-72); and Nikolai Krementsov (Medical History, 54, 1 (2010), 131-2).
} 
also referred to the voluminous study on 'heredity and physical signs of degeneration' conducted by his Kazan colleague Alexander Sholomovich, who had found practically no difference between mentally ill and healthy subjects in the prevalence of the 'degenerative characteristics' identified by Morel. ${ }^{80}$

Their scepticism regarding the very notion of 'racial degeneration' perhaps also blinded Gamaleia and Iudin to a clear 'class' bias underpinning much of early eugenics research and initiatives: neither paid it any attention in his survey. Other Russian observers, however, made a point of commenting upon it. Prince Petr Kropotkin, the eminent philosopher and theoretician of anarchism, who at the time was living in exile in Britain, took part in the proceedings of the 1912 London congress. He delivered a passionate speech that reflected a general sentiment popular among the Russian intelligentsia. 'Who were unfit?', - Kropotkin exclaimed rhetorically, - 'the workers or the idlers? The women of the people, who suckled their children themselves, or the ladies who were unfit for maternity because they could not perform all the duties of a mother? Those who produced degenerates in slums, or those who produced degenerates in palaces? ${ }^{, 81}$ He vehemently opposed proposals repeatedly voiced at the congress to sterilise the 'unfit': 'before recommending the sterilisation of the feeble-minded, the unsuccessful, the epileptic (Dostoevsky was an epileptic), was it not their [eugenicists' - N. K.] duty to study the social roots and causes of these diseases?' Kropotkin insisted that such social measures as the creation of healthy housing and the abolition of slums 'would improve the germ-plasm of the next generation more than any amount of sterilisation' ${ }^{82}$ In a 1914 encyclopaedia article on eugenics, anthropologist Krzywicky echoed Kropotkin's sentiment, arguing that 'negative' eugenic measures, such as sterilisation or segregation, represented merely 'the instrument of narrow class interests'. ${ }^{83}$

Both Gamaleia and Iudin stressed that the Russian medical community (and educated public more generally) needed to know what eugenics was and what was being done in its name. But both carefully maintained their status as impartial observers, not propagandists. Characteristically, neither called on his colleagues to join the eugenics movement: to take part in an international eugenic conference, to organise a eugenic institution (a society, a journal or a laboratory), or to lobby for the adoption of eugenic laws and regulations. Even though information about the forthcoming 1912 International Eugenics Congress had appeared well in advance on the pages of The Physician's Gazette, the country's most widely distributed medical periodical, no Russian physician attended the congress. ${ }^{84}$

\footnotetext{
${ }^{80}$ Aleksandr Sholomovich, Nasledstvennost' $i$ fizicheskie priznaki vyrozhdeniia u dushevno-bol'nykh i zdorovykh (Kazan: Kazan Imperial University, 1913). Iudin had reviewed Sholomovich's monograph for Modern Psychiatry and, though noting certain methodological deficiencies of his research, strongly endorsed his basic conclusions. See T. Iudin, 'A.S. Sholomovich, Nasledstvennost' i fizicheskie priznaki vyrozhdeniia u dushevno-bol'nykh i zdorovykh', SP, 10 (1913), 819-23.

81 See Problems in Eugenics, Vol. 2. Report on Proceedings of the First International Eugenics Congress held at the University of London, July 24th to 30th, 1912 (London: Kingsway, 1913), 50-51.

82 On Kropotkin's general attitude towards genetics and eugenics, see Álvaro Girón, 'Kropotkin between Lamarck and Darwin: The Impossible Synthesis', Asclepio, 55 (2003), 189-213.

${ }^{83}$ L. Krzhivitskii, 'Antropotekhnika', in Novyi entsiklopedicheskii slovar' (St Petersburg: F. A. Brokgauz i I. A. Efron, 1914), 3: 99-101, here - 100 .

84 See '1-i Mezhdunarodnyi s”ezd po evgenike (rasovoi gigiene)', Vrachebnaia gazeta, 40 (1911), 1260. Characteristically, the announcement used the term 'eugenics' as synonymous with 'racial hygiene'. Two Russian physicians attended another congress on 'genealogy, heredity and racial hygiene' organised by psychiatrist Robert Sommer in April 1912 in Gissen. See A.S. Sholomovich, 'Novoe techenie v uchenii o nasledstvennosti (po povodu Gissenskogo kongressa o nasledstvennosti)', SP, 6 (1912), 392-401, and A.S. Sholomovich, 'Pervyi kongress po genealogii', Nevrologicheskii vestnik, 19, 3 (1912), 582-602.
} 
Despite these numerous similarities, to a considerable degree, Gamaleia's and Iudin's overviews of eugenics read as if they were written about two different movements. Indeed, each of them even preferred to use a different name in his descriptions: while Gamaleia used 'eugenics' interchangeably with 'racial hygiene' and 'generative hygiene', Iudin insisted that 'eugenetics', not 'eugenics', was the most appropriate name for the movement. ${ }^{85}$ Each of the observers focused largely on those components/elements/tenets of eugenics, which resonated most with his personal interests. Each of them sought to demonstrate the relevance of certain components of eugenics to his own medical specialty, disciplinary agendas and scientific interests. And the very possibility of using eugenics for these purposes certainly played a role in drawing Russian commentators' attention to the early eugenics movement.

For Gamaleia, eugenics was first and foremost an extension of hygiene (preventive medicine) to a new sphere - human reproduction - thus simply supplementing the labour, communal, social, school, industrial, child, sex, military, maternal, naval, occupational and every other existing subset of hygiene as a theoretical and research field aimed at the prevention of disease. In contrast, for Iudin, eugenics was first and foremost an application of genetics to the issues of human (primarily, mental) health. In fact, each focused on a different constituent component of eugenics. Gamaleia concentrated on a general ideology underpinning much of eugenic discourse: the prevention (and thus eventual liquidation) of various 'social ills' supposedly rooted in heredity such as criminality, alcoholism, venereal disease or feeble-mindedness. Iudin, however, directed most of his attention to the alleged scientific foundation of this ideology - studies on the role of heredity in these 'social ills', and especially in mental illness, his own research subject.

The two observers also differed in their attitudes to the third major component of eugenics: social policies - both the actions deemed necessary to attain the eugenic goal of bettering humankind (such as sterilisation, marriage regulation or segregation), and the actors capable of implementing such policies, first of all, the state. Gamaleia maintained a decidedly neutral attitude, simply recounting sterilisation laws enacted by various state legislative bodies in Switzerland and the United States. In contrast, Iudin explicitly endorsed the critique of such policies, as based on insufficient knowledge, mounted by the eminent geneticists Bateson and Correns. Furthermore, he approvingly cited the scathing assessment of sterilisation produced by his St Petersburg colleague Sergei Preobrazhenskii. Published in Modern Psychiatry in 1912 under the characteristic title 'The surgical prophylaxis of degeneration', Preobrazhenskii's article forcefully proclaimed that 'Russian socio-medical thought ... will always reject the participation of physicians in such cruel policies [as the coerced sterilisation of inmates in state prisons and asylums]. ${ }^{, 86}$ Iudin also paid much more attention than did Gamaleia to 'positive' eugenic measures enacted through a conscientious choice made by individuals, and noted that the British Mental Deficiency Act had included special provisions to protect the rights of individuals.

\footnotetext{
${ }^{85}$ Iudin actually used the term evgenetika, a Russified version of the French word eugénetique - the title of the French major eugenic periodical.

${ }^{86}$ See S.A. Preobrazhenskii, 'Khirurgicheskaia profilaktika vyrozhdeniia', SP, 2 (1912), 110-7. Preobrazhenskii and Iudin shared a common interest in twins research: in 1910 Preobrazhenskii followed Sukhanov and Iudin with his own studies on 'psychoses in twins'. It seems likely that Iudin as the editor of bibliographic and chronicle sections of the journal facilitated the publication of this article that Preobrazhenskii had originally presented as a report to a meeting of physicians in St Petersburg.
} 
It seems that these differences stemmed from the commentators' different medical specialties, personal experiences and professional positions. Even though, as members of the Russian medical community, both Gamaleia and Iudin saw the 'healthification' of Russia as their primary goal, their attitudes towards the role of the state in achieving this goal differed substantially. As an independent research bacteriologist (in Odessa) and later a high-ranking public health officer (in St Petersburg), Gamaleia was much more sympathetic to granting the state the right to intervene in 'reproductive hygiene', as it had already done in other 'hygienic' areas, such as infectious diseases, housing, labour, transport, the military, etc. Most likely, his personal experiences of working in the provinces during the major outbreaks of epidemic diseases, especially, cholera, in the 1890s and 1900s, played an important role in his stance. These epidemics had instigated considerable popular unrest and, in certain instances, violent uprisings, whose first victims quite often were the very doctors who had tried to stop the spread of disease and to help its sufferers. The epidemics had demonstrated the utter incompetence and inability of local authorities to control the spread of contagious diseases throughout the empire. ${ }^{87}$ These experiences apparently convinced Gamaleia of the need to have a strong central agency capable of dealing effectively with recurrent epidemics that ravaged the country. Indeed, Gamaleia belong to a vocal minority of Russian physicians advocating an increased role for central government in all medical and public health issues: he strongly supported Georgii Rein's idea of establishing a special Ministry of Health in Russia. ${ }^{88}$ He obviously saw the central government as a source of authority and power necessary to implement and enforce the recommendations of public health professionals in the 'backward' empire.

In contrast, as a psychiatrist employed first by a zemstvo (in Kharkov) and then by a municipality (in Moscow) funded mental institutions, Iudin was leery about the ability of either central or local government bodies (and non-professionals more generally) to manage such institutions and to treat their patients properly. Along with the majority of Russian psychiatrists, he saw both the central government and local bureaucracies as a threat to the autonomy and authority of his profession. He played an active role in creating the Union of Russian Psychiatrists and Neurologists (and in arranging the Union's first congress in 1911), a union that was meant to affirm the authority and autonomy of physicians in the issues of mental health research, treatment and administration. ${ }^{89} \mathrm{He}$ certainly shared in the belief of many Russian physicians that their professional/scientific expertise gave them the ultimate authority to address the country's medical and public health issues and to direct medical services and public health efforts as they saw fit, thus delegating to state bodies merely a financing and enabling role in the 'healthification' of Russia.

\footnotetext{
${ }^{87}$ For an overview of the cholera epidemics and their role in shaping the attitudes of both physicians and state officials, see Henze, op. cit. (note 19).

${ }^{88}$ N. Gamaleia, 'O ministerstve narodnogo zdraviia', GiS, 20-21 (1910), 397-428.

89 On the general subject of the professionalisation and deprofessionalisation of Russian psychiatry, see Julia Brown, 'The Professionalization of Russian Psychiatry: 1857-1911' (unpublished PhD dissertation: University of Pennsylvania, PA, 1981); Julia Brown, 'A sociohistorical perspective on deinstitutionalization: the case of late imperial Russia', in S. Spitzes and A. Scull (eds), Research in Law, Deviance and Social Control (Greenwich, CT: JA1 Press, 1985), 7: 167-88; Julia Brown, 'Professionalization and radicalization: Russian psychiatrists respond to 1905', in Harley D. Balzer (ed.), Russia's Missing Middle Class: The Professions in Russian History (Armonk, NY: M. E. Sharpe, 1996), 169-96; and Julia Brown, 'The Deprofessionalization of Soviet Physicians: A Reconsideration', International Journal of Health Services, 17 (1987), 65-76.
} 


\section{The 'Eugenic Internationale' through the Eyes of Russian Physicians}

The striking differences in Gamaleia's and Iudin's commentaries on eugenics stemmed not only from their different medical specialties, personal experiences and professional positions. They also reflected the lack of uniformity in the early eugenic movement itself. The ability of Russian observers to adopt and adapt eugenic ideas, methods and rhetoric to their particular professional and disciplinary agendas demonstrates that early eugenics was a very loosely organised movement that lacked standard terminology, universal methodology and a consistent conceptual basis. It was merely an aggregate of various 'national eugenics', each of which had its own national roots, justifications, trajectories, patrons, institutions and aims, clearly manifested in such varying names as Anglo-American 'eugenics' and 'euthenics', German 'Rassenhygiene' and 'Fortpflanzungshygiene', and French 'eugénetique' and 'puériculture'. 90

More important, the proceedings of and debates at the 1912 London congress unambiguously showed that the movement's major players were not even interested in standardising their ideas, research practices (data collection and analysis), or policies. As Leonard Darwin asserted in his presidential address: 'In so new a field, wide differences of opinion as to the methods to be adopted are certain to exist, and it is only by a tolerant consideration of all these divergent views that the true path of progress will ever be discovered. ${ }^{91}$ This diversity of views allowed Russian commentators to pick and choose selectively from the pool of available ideas covered by the general umbrella of eugenics, liberally mixing Anglo-American 'eugenics' with German 'Rassenhygiene', French 'eugenitique', or Italian 'antropologia criminale'. ${ }^{92}$

This lack of interest in the uniformity of their views, methods, and concepts on the part of early eugenicists raises questions about the actual goals of their efforts to convene international congresses, form international organisations, and thus unite the varying 'national eugenics' into an international movement, as well as about their successes and failures in spreading the eugenic 'gospel' locally and internationally. In their innovative analysis of the 'transnational eugenics movement', the sociologists Deborah Barrett and Charles Kurzman have attributed the success of early eugenics on the international scene to a 'global culture' that appeared conducive to the movement's basic goals and concerns. ${ }^{93}$ They have identified two fundamental components (frames) of this global culture: the ideology of statehood and the ideology of personhood. In their view, the ideology of statehood in this period involved increasing state interventions into novel spheres of social and individual life, such as family, education, health, immigration and emigration, etc., thus expanding the state's purview far beyond such traditional areas of state authority as defence, law and order, and taxation. The concurrent ideology of personhood limited 'full personhood' only to propertied males (and in colonial settings

\footnotetext{
${ }^{90}$ For a different perspective on the early eugenics movement, see Stefan Kühl, For the Betterment of the Race: The Rise and Fall of the International Movement for Eugenics and Racial Hygiene (New York: Palgrave Macmillan, 2013).

${ }^{91}$ Leonard Darwin, 'Presidential address', in Problems in Eugenics, Vol. 1. Papers Communicated to the First International Eugenics Congress held at the University of London, July 24th to 30th, 1912 (London: Kingsway, 1912), 2.

92 For instance, Bjorn M. Felder's analysis of the works of another Russian commentator, Shepilevskii, convincingly demonstrates that Shepilevskii selectively focused his attention on the German racial hygiene and largely ignored the Anglo-American and the French 'national' versions of eugenics, see Felder, op. cit. (note 5).

93 D. Barrett and C. Kurzman, 'Globalizing Social Movement Theory: The Case of Eugenics', Theory and Society, 33 (2004), 487-527.
} 
only those of European ancestry) and included a strict hierarchisation of populations according to 'innate' ethnic, racial, class and gender characteristics. According to Barrett and Kurzman's argument, these particular ideologies permeated the global culture of the time and resonated strongly with early eugenic ideas and actions, thus enabling the success of eugenics as a transnational movement.

One might suggest, however, that these factors could account not only for the 'global success' but also for certain 'local failures' of eugenics. As we have seen, these particular ideologies of statehood and personhood appeared largely unacceptable to the Russian observers of eugenics. Most of them saw the Russian autocratic state's interventions as unwarranted and threatening to their professional aspirations and agendas. ${ }^{94}$ At the same time, the majority of Russian commentators perceived various social - class, race and gender - hierarchies constructed on the basis of 'biological', 'innate' characteristics as unsubstantiated. As we have seen, Russian observers were quite critical of the class and race biases of eugenics. Many among the Russian educated public were equally unsympathetic to the gender bias that occupied such a prominent place in eugenic ideas and actions. ${ }^{95}$ For instance, an article published in Russian Thought under the characteristic title 'Biologists on the Women Question' denied the 'inherent' 'biological inferiority' of women. ${ }^{96}$ This 'ideological incompatibility' probably played a significant role in the failure of early eugenics to lure Russian professionals into joining the movement.

Russian discussions of the early eugenics movement also suggest that one could add to Barrett and Kurzman's analysis one more useful component (frame): the ideology of scientific internationalism. ${ }^{97}$ As we have seen, the 'international character' of eugenics appeared a major point of attraction for its Russian observers. Given the membership composition of the early eugenics movement (which in general was limited to educated professionals and included a number of eminent scientists), together with the insistent claim of many eugenicists that eugenics was a 'science', this particular ideology probably played an important role in the success of early eugenics on national and international scenes. ${ }^{98}$

\footnotetext{
${ }^{94}$ For a general analysis of the attitudes of the Russian educated elites to the state's authority, see Joseph Bradley, 'Subjects into Citizens: Societies, Civil Society, and Autocracy in Tsarist Russia', American Historical Review, 107, 4 (2002), 1094-123.

95 On eugenics and gender, see Alexandra Mina Stern, 'Eugenics and sexuality: a global tour and compass', in A. Bashford and $\mathrm{Ph}$. Levine (eds), The Oxford Handbook on the History of Eugenics (New York: Oxford University Press, 2010), 173-91; and Susan Klausen and Alison Bashford, 'Fertility control: eugenics, neo-malthusianism, and feminism', in Bashford and Levine (eds), 98-115.

96 L.E. Obolenskii, 'Biologi o zhenskom voprose', Russkaia mysl', 2 (1893), 61-78. On the Russian intelligentsia's general attitudes towards the 'women question', see Richard Stites, The Women's Liberation Movement in Russia:Feminism, Nihilism, and Bolshevism, 1860-1930 (Princeton, NJ: Princeton University Press, 1978). For the first attempt to examine Russian eugenicists' attitudes to the issues of gender and ethnicity, see Birte Kohtz, 'Gute Gene, schlechte Gene: Eugenik in der Sowjetunion zwischen Begabungsforschung und genetischer Familienberatung', Jahrbücher für Geschichte Osteuropas, 61, 4 (2013), 591-610. Alas, this article focuses exclusively on the Soviet period.

97 The involvement of several early proponents of eugenics (such as, for instance, David S. Jordan) in the nascent peace movement also suggests that perhaps a more general ideology of an 'international dialogue' also played a role in the movement's success on the international scene before, and especially after, World War I.

98 See, for instance, Paul Weindling, 'The "Sonderweg" of German Eugenics: Nationalism and Scientific Internationalism', British Journal of the History of Science, 22 (1989), 321-33; Paul Weindling, 'International Eugenics: Swedish Sterilization in Context', Scandinavian Journal of History, 24 (1999), 179-97; Alison Bashford, 'Internationalism, cosmopolitanism and eugenics', in Bashford and Levine (eds), The Oxford Handbook on the History of Eugenics, 254-86.
} 
The decades before the First World War were the heyday of scientific internationalism characterised by the growing number of international meetings, journals, expeditions, and societies in practically every scientific field and discipline. This emerging 'scientific internationale' was based on the notion of the universality of scientific knowledge and was aimed primarily at the creating and maintaining of a disciplinary consensus regarding research methods, subjects, concepts, terms and objectives in specific fields of knowledge. But all of these international organisations and activities also conferred on their participants from various countries shared 'transnational' prestige and authority. As numerous studies of 'international science' have demonstrated, such prestige and authority associated with participation in international activities and organisations proved highly instrumental in the advancement of scientists' 'national' interests and agendas, for instance, in courting domestic patrons or mobilising local resources and allies. ${ }^{99}$

One could suggest that even though many activists of the international eugenics movement were not particularly interested in the building of a disciplinary consensus, they definitely sought to capitalise on the authority and prestige attached to 'international science' in the era before the First World War. A noticeable increase in the number of publications on eugenics in Russian professional and popular periodicals after the London congress demonstrates that they certainly succeeded in accomplishing this goal: the congress did attract the close attention of numerous observers. This could be further illustrated by the rapid development of 'national' eugenic organisations in France, Italy and Scandinavian countries in the aftermath of the congress. ${ }^{100}$ For the most part, the very same individuals who had attended the congress spearheaded this development, suggesting that their attendance of the international gathering was a weighty argument in persuading their local patrons and colleagues of the necessity to organise 'national eugenics' in their home countries. The first meeting of the Permanent International Eugenics Committee in Paris in 1913 certainly helped the organisational efforts of French and Belgian would-beeugenicists (Belgium was to host the next 1914 meeting), and the advancement of their 'national' agendas. ${ }^{101}$

Thus, the very lack of cohesiveness in the early eugenics movement gave it a unique strength. The loose mix of widely varying ideas, ideals, methods, policies, activities and proposals offered to a variety of educated professionals in numerous countries the possibility of choosing, adopting, and adapting particular elements of early eugenics to their own national, professional, institutional and disciplinary contexts, interests

\footnotetext{
99 See, for instance, Jean-Jacques Salomon, 'The "Internationale” of Science', Science Studies, 1 (1971), 24 42; Brigitte Schroeder-Gudehus, 'Nationalism and internationalism', in R. Olby et al. (eds), Companion to the History of Modern Science (London and New York: Rutledge, 1989), 909-19; Paul Weindling (ed.), International Health Organisations and Movements, 1918-39 (Cambridge: Cambridge University Press, 1995); and Nikolai Krementsov, International Science between the World Wars: The Case of Genetics (London: Routledge, 2005). ${ }^{100}$ For general histories of eugenics in France, see William H. Schneider, Quality and Quantity: The Quest for Biological Regeneration in Twentieth-Century France (Cambridge: Cambridge University Press, 1990), and Anne Carol, Histoire de l'eugénisme en France: Les médecins et la procréation XIXe-XXe siècle (Paris: Le Seuil, 1995); in Italy, Francesco Cassata, Building the New Man: Eugenics, Racial Science and Genetics in TwentiethCentury Italy (Budapest: Central European University Press, 2011); and in Scandinavia, Gunnar Broberg and Nils Roll-Hansen (eds), Eugenics and the Welfare State: Sterilization Policy in Denmark, Sweden, Norway and Finland (East Lansing, 1996).

101 Similarly, the post-war meetings of the Committee (later the International Federation of Eugenic Organizations) held during the 1920s - in New York City (1921), Brussels (1922), Lund (1923), Milan (1924), London (1925), Paris (1926), Amsterdam (1927), Munich (1928), and Rome (1929) - certainly facilitated the growth of 'national eugenics' in the host countries, as well as the spread of the 'gospel' of eugenics throughout the world.
} 
and agendas. It was this very looseness of early eugenics that attracted numerous anthropologists, educators, doctors, public health activists, social reformers, biologists and jurists in various countries under the banners of the international eugenics movement in the period before the First World War. But Russian professionals joined the movement only after the Great War and the 1917 Bolshevik revolution had radically reshaped the cultural, ideological, and political terrain of their homeland. ${ }^{102}$

102 For detailed analyses of the development of eugenics in Soviet Russia, see Adams, op. cit. (notes 3 and 6) and Krementsov, op. cit. (note 4). 